\title{
Etika Penjualan dalam Perspektif Islam
}

\author{
Moh Nasuka \\ UIN Sunan Kalijaga Yogyakarta \\ nasucha_durri@yahoo.com
}

\begin{abstract}
:
Ethics is the orientation vehicle for human endeavor to answer a very fundamental question, how human should live and act, and many other questions. However, the reality has shown that no human can carry out their lives perfectly and satisfyingly. Ethical behavior in the utilitarian emphasis on positivistic approach, but it ignores all aspects of the transcendental. Secular theories interpreted according to the desires and behaviors of the businesses people, which have an impact on the failure of ethics in providing a meaningful service. Many cases of ethical violations performed by sales person affect a large quantity of company losses. Islamic views on ethics are absolute rather than relative, it has a strong foundation based on principles of fairness and justice, through the attitude of sidq, fatanah, amanah, tabligh. Whole series of activities in one's life will be accountable before God.
\end{abstract}

Keywords: Ethics, Behaviour, Ethics Philosophy, Islamic ethical philosophy.

\begin{abstract}
Abstrak:
Etika adalah wahana orientasi bagi usaha manusia untuk menjawab suatu pertanyaan yang amat fundamental, bagaimana manusia harus hidup, bagaimana bertindak, dan lain-lain. Akan tetapi, kenyataan telah menunjukkan bahwa tidak ada satu pun manusia mampu melaksanakan tata kehidupannya secara sempurna dan memuaskan dalam kesendiriannya. Etika perilaku dalam utili tarian menekankan pada pendekatan positivistik, namun mengabaikan semua aspek transendental. Teori-teori sekuler ditafsirkan menurut keinginan dan perilaku dari masing-masing pelaku bisnis, yang berdampak pada kegagalan etika dalam memberikan layanan yang penuh arti. Banyak terjadi kasus pelanggaran etika tenaga penjualan yang mengakibatkan kerugian perusahaan dalam jumlah yang cukup besar. Pandangan Islam terhadap etika bersifat mutlak bukan relatif, memiliki pondasi yang kuat yang mendasarkan pada prinsip-prinsip kejujuran dan keadilan, melalui sikap sidik,
\end{abstract}


fatanah, amanah, tabligh. Seluruh rangkaian aktivitas dalam kehidupan seseorang akan dipertanggungjawabkan di hadapan Allah.

Kata Kunci: Etika, Perilaku, Filosofi Etika Konvensional, Filosofi Etika dalam Islam.

\section{Pendahuluan}

Sejak hampir tiga dasawarsa terakhir, berbagai kalangan menaruh perhatian yang cukup tajam terhadap etika. Kajian terhadap etika mulai menemukan jati dirinya. Penemuan jati diri ini melalui proses yang cukup panjang, yaitu semenjak adanya evaluasi terhadap manusia dan kehadiran orang lain selain dirinya, hingga munculnya perkembangan basis teknologi yang berimplikasi pada kehidupan dunia nyata.

Etika merupakan refleksi manusia tentang apa yang dilakukan dan dikerjakannya. Etika adalah wahana orientasi bagi usaha manusia untuk menjawab suatu pertanyaan yang amat fundamental, bagaimana manusia harus hidup, bagaimana bertindak, dan lain-lain. Etika menuntun orang agar sungguh-sungguh menjadi orang baik, agar memiliki sikap etis, dengan mengutamakan kejujuran dan kebenaran.

Kenyataan telah menunjukkan bahwa tidak ada satu pun manusia mampu melaksanakan tata kehidupannya secara sempurna dan memuaskan dalam kesendiriannya. Manusia tidak bisa terlepas dan terbebas dari tatanan nilai. Namun, dalam tata pergaulan antara manusia satu dengan lainnya hampir dapat dipastikan bahwa kehendak bebas yang sebebas-bebasnya tidak pernah dapat terwujud. Terdapat sejumlah benturan yang harus diwujudkan menjadi setara dan berimbang antar manusia dalam tata pergaulan itu. Oleh karena benturan itulah maka estetika pergaulan yang serasi dan selaras harus diwujudkan dan harus dapat dikembalikan kepada jalinan nilai agar semua pihak dapat menerimanya secara moral. Pengembalian hakikat secara moral itu dilandasi pada filosofi bahwa nilai moral adalah perwujudan hak-hak dasar manusia, sehingga sudah sepatutnya dikedepankan. 


\section{Etika, Moralitas, Norma, Budaya, dan Agama.}

Secara epistemologi, kata etika berasal dari bahasa Yunani ethos (bentuk tunggal). Ethos berarti tempat tinggal, padang rumput, kandang, kebiasaan, adat, watak, perasaan, sikap, dan cara berpikir. Bentuk jamaknya tha etha yang berarti adat istiadat. Diperkirakan terminologi istilah inilah yang kemudian berkembang menjadi etika. Secara etimologis, etika berarti ilmu tentang apa yang biasa dilakukan sebagai suatu tatanan kepatuhan, adat istiadat, yang berkenaan dengan hidup yang baik dan buruk (Wiranata, 2010: 2).

William K. Frankena dalam Ethics (1973), menegaskan bahwa sebagai filsafat moral, etika identik dengan berpikir falsafi tentang moralitas, persoalan-persoalan moral, dan keputusan-keputusan moral (Yosephus, 2010: 26).

Etika senantiasa terkait dengan konsep ideal yang memuat tatanan etik dalam pergaulan yang melandasai tingkah laku untuk mewujudkan tata hubungan pergaulan manusia berdasarkan kepada asas-asas baku, ideal, dan penuh harmonisasi bila dilakukan. Dengan demikian etika merupakan filsafat moral yaitu pemikiran yang dilandasi oleh rasional, kritis, mendasar, sistematis, dan normatif. Dalam konteks profesionalisme, etika memberikan jawaban dan sekaligus pertanggungjawaban tentang ajaran moral, yaitu bagaimana seorang yang berprofesi harus bersikap, berperilaku, dan mempertanggungjawabkan perbuatannya. Pokok pangkal etika adalah perbuatan baik dan benar, oleh karena itu etika adalah filsafat moral, sebagai bagian dari filsafat (Wiranata, 2010: 8).

Ciri moral ialah mengandalkan kesadaran manusia. Oleh karena itu, manusia tidak berbuat semaunya sendiri atau tidak berbuat sesuatu. Keseluruhan perilaku manusia diatur atau ditentukan oleh norma moral yang berlaku umum bagi semua manusia (universal), manusia dibentuk oleh moral. Perbuatan manusia yang berlandaskan sejumlah syarat-syarat moral dinyatakan sebagai perbuatan baik, demikian sebaliknya apabila tidak didasarkan pada pemenuhan persyaratan dinyatakan sebagai perbuatan tidak baik (Wiranata, 2010: 8).

Norma-norma moral adalah tolok ukur yang dipakai sebagai dasar oleh masyarakat untuk mengukur sampai sejauh mana kebaikan seseorang 
itu dalam rangka interaksi sosialnya. Norma-norma atau kaidah-kaidah moral yang dipakai untuk mengukur perilaku seseorang dijunjung tinggi oleh masyarakat karena telah menghasilkan ketenangan, kesenangan, dan kesejahteraan hidup bagi masyarakat (Yosephus, 2010: 200).

Sebuah tindakan yang baik dari segi moral ialah tindakan bebas manusia yang mengafirmasi nilai moral objektif dan mengafirmasi hukum moral. Sumber dari kepatuhan dan ketidakpatuhan moral terletak pada keputusan bebas kehendak, sikap bijak yang timbul dari keputusan bebas tersebut, dan pribadi atau subjek moral. Walaupun moralitas dihubungkan dengan sikap dan perilaku individu, namun individu-individu hanya bisa bersikap dalam konteks masyarakat yang memiliki budaya, struktur sosial, politik, dan ekonomi tertentu (Wiranata, 2010: 8).

Etika, hubungan dengan budaya, bahwa kebudayaan suatu suku bangsa kemungkinan tidak sama dengan kebudayaan suku bangsa lain, atau bahkan bertentangan, misalnya memegang kepala orang lain, di Indonesia dianggap tidak sopan, tetapi di Amerika Serikat biasa saja. Di sinilah diperlukan suatu etika untuk memahami perilaku antar suku bangsa yang berlainan.

Hubungan antara etika dan agama, etika sama sekali tidak dapat menggantikan agama, namun sekaligus juga etika tidak bertentangan dengan agama. Secara hakiki, etika membantu para pemeluk suatu agama agar memahami secara mendalam agama yang dianutnya (Yosephus, 2010: 36).

Lebih lanjut dikatakan, bahwa ajaran moral yang bersifat umum terdapat dalam semua agama, misalnya larangan untuk membunuh, mencuri, berzina, berbohong, dan lain-lain. Demikian halnya dengan kewajibankewajiban yang bersifat umum yang dijunjung tinggi dalam semua agama, misalnya berlaku jujur, berlaku adil, membantu yang lemah dan tak berdaya, mendahulukan mereka dalam pelayanan umum, dan lain-lain (Yosephus, 2010: 37).

Pada dasarnya jenis-jenis etika, menurut Yosephus (2010), identik dengan analisis tentang pendekatan-pendekatan ilmiah terhadap tingkah dan tindakan manusia dalam bingkai moralitas. Sampai saat ini umumnya disepakati oleh para filsuf etikawan perihal adanya tiga jenis etika, yaitu: etika deskriptif, etika normatif, dan etika metaetika (Yosephus, 2010: 1423). 
Etika deskriptif, hanya menggambarkan atau melukiskan tingkah dan perbuatan manusia, sama sekali tidak memberikan penilaian apapun terhadap etika moral (tingkah dan tindakan manusia) yang dihadapi.

Etika normatif, membuat prinsip etis menjadi masuk akal dan operasional sehingga dapat dipertanggungjawabkan, tidak akan berhenti dengan menggambarkan perilaku atau tindakan manusia apa adanya (deskriptif), melainkan harus memberikan penilaian-penilaian moral kemudian menentukan benar-tidaknya dan tepat-tidaknya tingkah dan tindakan serta anggapan moral.

Etika normatif dikelompokkan dalam dua jenis, yakni: 1). Etika umum atau norma moral yang berlaku bagi semua orang di mana mereka berada, misalnya norma moral, norma hukum dan norma sopan santun; 2). Etika khusus atau norma moral yang hanya berlaku di suatu tempat atau untuk suatu lingkup tertentu saja, misalnya etika bisnis, etika politik, etika medik, etika komunikasi, etika akuntan publik, etika lingkungan hidup, dan lainlain.

Etika normatif juga dapat dibedakan dari segi benar dan tidaknya suatu tindakan dan baik-buruknya akibat yang ditimbulkan oleh tindakan tersebut, yakni: 1) Etika Deontologis, dimana hanya merujuk kepada keniscayaan atau keharusan atau kewajiban, artinya hanya merujuk kepada sistem yang mengikat bukan karena konsekuensi atau akibat-akibat yang ditimbulkan, melainkan semata-mata hanya karena norma atau sistem tersebut benar dan baik, misalnya menyalami orang lain merupakan tindakan yang benar dan baik secara moral; 2) Etika Teleologis, yang merupakan disiplin ilmu atau studi tentang gejala-gejala yang menunjukkan arah, tujuan atau maksud serta bagaimana sesuatu diperoleh dalam dan melalui suatu proses. Suatu tindakan diterima sebagai benar atau keliru dan baik atau jelek tergantung pada baik buruknya akibat yang ditimbulkan oleh tindakan tersebut.

Metaetika, merupakan salah satu cara lain untuk menerapkan norma dan nilai-nilai etika dalam posisinya sebagai ilmu, yakni sebagai fislsafat moral. Metaetika dimunculkan dan diaplikasikan pada saat mengkaji ucapanucapan atau ungkapan di bidang moral atau yang berhubungan dengan moralitas manusia. 


\section{Filosofi Etika Konvensional}

Etika berkaitan dengan orthopraxis, yakni tindakan yang benar (right action). Persoalannya adalah, kapan dan dalam kondisi bagaimana suatu perbuatan dinyatakan sebagai suatu kebenaran. Jawaban atas pertanyaan ini ditafsirkan secara berbeda dan bervariasi, yang akhirnya berkembang menjadi sejumlah teori sebagaimana diuraikan sebagai berikut (Wiranata, 2010: 22-26):

a). Teori Utilitarian. Utilitarisme berasal dari bahasa Latin utilis, yang berarti berguna, berfaedah, menguntungkan. Menurut aliran ini prinsip pokok yang harus dikedepankan dalam berbuat adalah asas manfaat/ asas keunt ungan. Perilaku dan perbuatan manusia dikatakan baik bila mendatangkan keuntungan dan kegunaan. David Hume, Jeremy Bentham, dan Stuart Mill adalah sebagian dari penggagas aliran ini. Namun pendapat ini tidak dapat diberlakukan secara universal, sebab nilai guna tidak mungkin bermakna seragam pada semua manusia, apalagi dipergunakan untuk menilai persoalan moral.

b). Teori Deontologi. Deontologis berasal dari bahasa Yunani deon, yang berarti kewajiban atau sesuatu yang harus dilakukan. Deontologis pada hakekatnya menitiikberatkan pada maksud seseorang melakukan suatu perbuatan. Filsuf Jerman Immanuel Kant merupakan salah satu penggagas aliran ini. Baik buruk suatu perbuatan dinilai dari sudut tindakan itu sendiri dan bukan dari akibat yang ditimbulkannya (berdasarkan maksud si pelaku, sehingga wajib untuk dilakukan). Kritik berkaitan terhadap aliran deontologist, berkaitan dengan pemenuhan kewajiban yang pada umumnya dititik beratkan pada otonomi moral pribadi manusia bersangkutan. Dengan demikian fenomena deontologist tampak seolaholah kaku, karena tidak mungkin melakukan suatu perbuatan di luar batasan-batasan yang ada.

c). Toeri Naturalisme. Naturalisme berasal dari kata nature (Inggris) yang berarti alam. Menurut aliran ini baik bauruk suatu perbuatan hakekatnya harus dikembliakan kepada sifatnya yang alami yaitu tidak merusah alam dan ligkungan. J.J. Rousseau merupakan salah satu penggagas aliran ini. 
d). Teori Teleologis. Teleology berasal dari bahasa Yunani telos yang berarti tujuan atau manfaat. Aliran ini mendasarkan atas tujuan/manfaat dan hasilan yang diperoleh dalam menilai manfaat sebuat perbuatan. Apapun yang dilakukan asal manfaatnya lebih besar, pada dasarnya dapat dilakukan.

e). Teori Hedonisme. Hedonisme berasal dari bahasa Yunani hedone yang berarti senang, nikmat, kegembiraan. Aliran hedonisme mengendepankan tujuan aktivitas manusia terletak pada kesenangan sebagai tujuan akhir. Asal menghasilkan kesenangan atau kebaikan, maka apapun yang diperbuat manusia pada dasarnya adalah baik. Aristippos dari Kyrene, Epikuros, John Lokce, dan James Mill merupakan sebagian dari tokohtokoh aliran hedonism. Kritik atas aliran ini dilakukan, karena kenikmatan yang ternyata di dalam praktik bersifat bermacam-macam dan tidak ada kenikmatan yang bersifat dan bermakna seragam pada semua orang.

f). Teori Eudaimonisme. Eudaimonisme berasal dari kata Yunani eudaimonia, menitikberatkan pada ada tidaknya tujuan yang mendahului pelaksanaan aktivitas manusia. Bagi Aristoteles, tujuan tertinggi adalah kebahagiaan (eudaimonia). Setelah kebahagiaan yang dicita-citakan maka seseorang tidak akan melakukan apapun lagi. Pendapat ini dikritik, karena kebahagiaan yang hendak dicari hanya kebahagiaan yang semata-mata sifatnya horizontal, sifat vertikalnya tidak diperhitungkan.

g). Teori Vitalisme. Vitalisme berasal dari bahasa Latin vita yang berarti kehidupan. Aliran ini memandang nilai yang tertinggi dalam kehidupan manusia terletak pada kehidupan. Perbuatan dinyatakan sebagai suatu yang baik bila mampu memberikan nilai tambah pada daya hidup. Tokoh aliran ini diantaranya adalah Albert Schweizer.

\section{Filosofi Etika dalam Islam}

Perilaku yang etis dalam utilitarian menekankan pada pendekatan positivistik (pengalaman) namun mengabaikan semua aspek transendental atau aktualisasi tujuan hidup rohani yang lebih tinggi (Safi, L., 1996).

Teori-teori sekuler tersebut memiliki tiga keterbatasan utama. Pertama-tama, konsep-konsep dari keadilan dan utilitas telah diartikan dengan pandangan yang dangkal dan sempit. Kedua, dengan mengabaikan aspek 
transendental, teori-teori ini bersifat tidak lengkap dan terbatas dalam penerapan dan kegunaannya. Ketiga, dua kekurangan ini menyebabkan teoriteori sekuler ditafsirkan menurut keinginan dan perilaku dari masing-masing pelaku bisnis, yang berdampak pada kegagalan etika dalam memberikan layanan yang penuh arti (Forsyth, 1980: 175-184).

Pandangan Islam memiliki pondasi yang kuat yang mendasarkan pada prinsip-prinsip kejujuran dan keadilan, dan memberikan arah dan tujuan dalam menciptakan nilai dan meningkatkan standar kehidupan masyarakat melalui usaha komersial selama mengikuti prinsip-prinsip ini. Pandangan Islam memberikan catatan yang sangat berharga dan sungguh unik mengenai aspek khusus tentang aktivitas manusia melalui tiga alasan (Forsyth, 1980: 175-184): Pertama, Islam tidak mengakui adanya pemisahan antara urusan duniawi dan ukhrawi selama individu mencari keridhaan Allah dan mengikuti perintah-Nya dalam melakukan seluruh aspek aktivitas sehari-hari (Nadwi, 1978). Kedua, semua jenis usaha seseorang, termasuk usaha yang bertujuan komersial merupakan bagian dari kepercayaan agama (Al-Faruqi, 1992). Dengan kata lain, segala sesuatu yang dilakukan seseorang adalah bagian dari ibadah kepada Allah. Ketiga, dalam Islam, semua usaha komersil (termasuk pemasaran nasional ataupun internasional) merupakan bentuk kegiatan dari ibadah (QS:107: 1-7). Kesimpulannya adalah seluruh rangkaian aktivitas dalam kehidupan seseorang akan dipertanggungjawabkan di hadapan Allah. Melakukan transaksi-transaksi bisnis merupakan bagian dari kehidupan yang hakiki sehari-hari, dalam Islam setiap transaksi harus dilaksanakan menurut ajaran hukum Islam.

Menurut Muslich (2004), nilai baik atau ma'ruf dan nilai buruk atau mungkar bersifat universal. Hal ini sesuai dengan perintah Allah kepada manusia untuk melakukan perbuatan ma'ruf dan menghindari perbuatan mungkar atau jahat dalam Surah Ali Imran [3]: 104, yang artinya:

"Dan hendaklah ada di antara kamu segolongan umat yang menyeru kepada kebaikan, menyuruh kepada yang makruf dan mencegah dari yang munkar; merekalah orang-orang yang beruntung”.

Kebenaran agama yang didasarkan pada wahyu dari Allah yang dijamin kebenarannya terbukti sering diperkuat oleh kebenaran yang dihasil- 
kan oleh banyak penelitian ilmu pengetahuan (Muslich, 2004: 28-29).

\section{Perilaku}

Perilaku didefinisikan sebagai: (1) segala sesuatu yang dilakukan oleh manusia, dan (2) perubahan dalam materi atau non materi yang disebabkan langsung oleh manusia (Bagozzi, 1980; Fishbein \& Ajzen, 1975). Perilaku juga merupakan hasil dari proses mental. Sikap dan niat adalah contoh dari variabel-variabel mental yang mempengaruhi perilaku (Ellis \& Hunt, 1993 dalam Sihombing, 2004: 36).

Munurut Bagozzi (1980), perilaku dapat dibedakan menjadi tindakan, kegiatan, dan hubungan. Tindakan adalah pergerakan fisik dalam waktu yang pendek. Kegiatan didefinisikan sebagai tindakan-tindakan yang berulang kali dalam waktu yang relatif panjang. Sedangkan hubungan didefinisikan sebagai pertukaran antara memberi dan menerima.

Perilaku manusia adalah sekumpulan perilaku yang dimiliki oleh manusia dan dipengaruhi oleh adat, sikap, emosi, nilai, etika, kekuasaan, persuasi, dan/atau genetika. Selanjutnya menurut Myers (1983), perilaku adalah sikap yang diekspresikan (expressed attitudes). Perilaku dengan sikap saling berinteraksi, saling mempengaruhi satu dengan yang lain.

Perilaku manusia dipelajari dalam ilmu psikologi, sosiologi, ekonomi, antropologi dan kedokteran. Perilaku seseorang dikelompokkan ke dalam perilaku wajar, perilaku dapat diterima, perilaku aneh, dan perilaku menyimpang.

Perilaku atau aktivitas pada individu atau organisme tidak timbul dengan sendirinya, tetapi sebagai akibat dari stimulus yang diterima oleh organisme yang bersangkutan baik stimulus eksternal maupun stimulus internal. Perilaku individu dapat mempengaruhi individu itu sendiri, di samping itu perilaku juga berpengaruh pada lingkungan. Demikian pula lingkungan dapat mempengaruhi individu, demikian sebaliknya. Oleh sebab itu, dalam perspektif psikologi, perilaku manusia (human behavior) dipandang sebagai reaksi yang dapat bersifat sederhana maupun bersifat kompleks (Bandura, 1977; Azwar, 2003). 
Lebih lanjut, Icek Ajzen dan Martin Fishbein (1980, dalam Brehm and Kassin, 1990) mengemukakan teori tindakan beralasan (theory of reasoned action). Dengan mencoba melihat anteseden penyebab perilaku volisional (perilaku yang dilakukan atas kemauan sendiri), teori tindakan beralasan ini didasarkan pada asumsi-asumsi: (a) bahwa manusia pada umumnya melakukan sesuatu dengan cara-cara yang masuk akal; (b) bahwa manusia mempertimbangkan semua informasi yang ada; dan (c) bahwa secara eksplisit maupun implisit manusia memperhitungkan implikasi tindakan mereka.

Teori tadi kemudian diperluas dan dimodifikasi oleh Ajzen (1988) dengan teori perilaku terencana (theory of planned behavior), di mana determinan intensi tidak hanya dua (sikap terhadap perilaku yang bersangkutan dan norma-norma subjektif) melainkan tiga dengan diikutsertakannya aspek kontrol perilaku yang dihayati (perceived behavioral control). Keyakinankeyakinan berpengaruh pada sikap terhadap perilaku tertentu, pada normanorma subjektif, dan pada kontrol perilaku yang dihayati. Keyakinan mengenai perilaku apa yang bersifat normatif dan motivasi untuk bertindak sesuai dengan harapan normatif tersebut membentuk norma subjektif dalam diri individu. Kontrol perilaku ditentukan oleh pengalaman masa lalu dan perkiraan individu mengenai seberapa sulit atau mudahnya untuk melakukan perilaku yang bersangkutan.

Perilaku memiliki karakteristik sebagai berikut: 1). Perilaku adalah perkataan dan perbuatan individu. Jadi apa yang dikatakan dan dilakukan oleh seseorang merupakan karakteristik dari perilakunya, 2). Perilaku mempunyai satu atau lebih dimensi yang dapat diukur, yaitu : frekuensi, durasi, dan intensitas, 3). Perilaku dapat diobservasi, dijelaskan, dan direkam oleh orang lain atau orang yang terlibat dalam perilaku tersebut, 4). Perilaku mempengaruhi lingkungan, lingkungan fisik atau sosial, 5). Perilaku dipengaruhi oleh lingkungan (lawful), 6. Perilaku bisa tampak atau tidak tampak. Perilaku yang tampak bisa diobservasi oleh orang lain, sedangkan perilaku yang tidak tampak merupakan kejadian atau hal pribadi yang hanya bisa dirasakan oleh individu itu sendiri atau individu lain yang terlibat dalam perilaku tersebut. 


\section{Etika Penjualan dalam Perspektif Islam}

Etika atau adab, menurut Imam An-Nawawi dalam kitabnya Riyadhus Shalihin, adalah tata krama yang dilakukan seseorang (Al-Utsaimin, 2007: 38). Etika dalam Islam, menyangkut norma dan tuntunan atau ajaran yang mengatur sistem kehidupan individu atau lembaga (corporate), kelompok dan masyarakat dalam interaksi hidup antar individu, antar kelompok atau masyarakat dalam konteks bermasyarakat maupun dalam konteks hubungan dengan Allah dan lingkungan. Di dalam sistem etika Islam ada sistem penilaian atas perbuatan atau perilaku yang bernilai baik dan bernilai buruk (Muslich, 2004: 25-26).

Perilaku baik menyangkut semua perilaku atau aktivitas yang didorong oleh kehendak akal fikir dan hati nurani dalam berkewajiban menjalankan perintah Allah dan termotivasi untuk menjalankan anjuran Allah.

Perilaku buruk menyangkut semua aktivitas yang dilarang oleh Allah dimana manusia dalam melakukan perilaku buruk atau jahat ini terdorong oleh hawa nafsu, godaan syaitan untuk melakukan perbuatan atau perilaku buruk atau jahat yang akan mendatangkan dosa bagi pelakunya dalam arti merugikan diri sendiri dan yang berdampak pada orang lain atau masyarakat.

Sementara menurut Al-Ghazali, akhlak adalah gambaran tentang kondisi yang menerap di dalam jiwa. Semua perilaku yang bersumber dari akhlak tidak memerlukan proses berpikir dan merenung. Perilaku baik dan terpuji yang berasal dari sumber di jiwa disebut al-akhlaq al-fadhilah atau akhlak baik dan berbagai perilaku buruk disebut al-akhlaq al radzilah atau akhlak buruk (Ghazali, 2004:68).

Rasulullah SAW., adalah manusia pertama yang dituju dan dikehendaki oleh Allah SWT., yang diberi pengajaran-pengajaran dan pendidikanpendidikan tentang perilaku yang baik dan terpuji. Selanjutnya dari beliau itulah memancarnya cahaya keagungan budi pekerti ke seluruh umat manusia, sebab beliau dididik dengan Alqur'an dan itu pulalah yang digunakan sebagai pedoman untuk mendidik umatnya. Oleh sebab itu Rasulullah SAW., bersabda:

"Aku ini diutus untuk menyempurnkan kemuliaan budi pekerti." Diriwayatkan oleh Ahmad, Hakim, dan Baihaqi. (Addimasyqi, t.t.: 469) 
Selanjutnya Rasulullah SAW., juga mengajak seluruh umatnya supaya berperangai dan berbudi pekerti yang luhur serta akhlak yang mulia. Setelah Allah menyempurnakan akhlaknya, lalu beliau dipujinya dan diberinya gelar sebagai orang yang berbudi agung dan luhur, sebagaimana firmanNya:

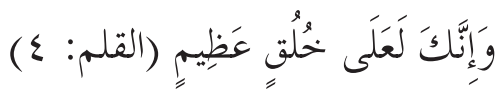

"Sesungguhnya engkau itu (wahai Muhammad) niscaya memiliki budi pekerti yang luhur sekali" (QS. Al Qalam [68]: 4).

Dalam pada itu, Rasulullah SAW., juga menjelaskan kepada seluruh umat manusia bahwa Allah SWT., itu mencintai budi pekerti yang luhur dan membenci yang buruk. Ajaran budi pekerti itu tercakup dalam sebuah ayat:

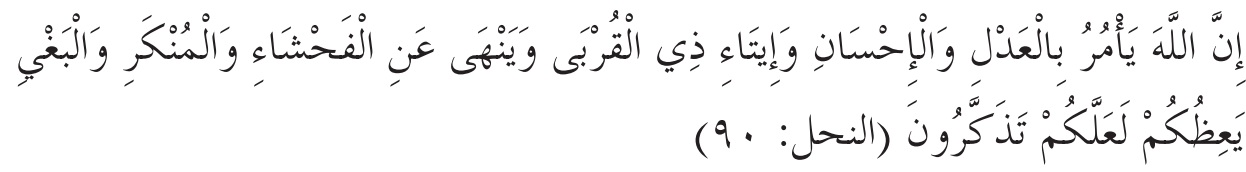

Yang artinya:

"Sesungguhnya Allah menyuruh (kamu) berlaku adil dan berbuat kebajikan, memberi kepada kaum kerabat, dan Allah melarang dari perbuatan keji, kemungkaran dan permusuhan. Dia memberi pengajaran kepadamu agar kamu dapat mengambil pelajaran. (QS. An-Nahl [16]: 90).

Selanjutnya, tinjauan literatur tentang perilaku, kaitannya dengan perilaku etika tenaga penjualan secara konvensional, Hunt dan Vitell, (1986: 5-16) menyatakan bahwa definisi perilaku etis maupun tidak etis, didasarkan pada sejauh mana sebuah tindakan yang dilakukan dianggap benar atau salah, baik atau jahat, jujur atau tidak jujur, ataupun adil atau tidak adil. Berbeda dengan pandangan konvensional, tinjauan literatur dalam pembahasan menggunakan pendekatan dasar-dasar hukum syariat Islam yang bersumber dari Alquran dan As-Sunnah. Hal ini akan sejalan dengan salah satu prinsip pokok kebijakan pengembangan perbankan syariah bahwa mengingat perbankan syariah adalah sistem perbankan yang mengedepankan moralitas, dan etika, maka nilai-nilai yang menjadi dasar dalam pengaturan dan 
pengembangan serta nilai-nilai yang harus diterapkan dalam operasi perbankan adalah siddiq, istiqomah, tabligh, amanah, fatonah. Selain itu adalah penerapan nilai nilai-nilai kerjasama ( $t a$ 'awun), pengelolaan yang profesional ( $r i$ 'ayah), dan tanggung jawab (masuliyah) dan upaya bersama-sama dan terus menerus melakukan perbaikan atau fastabiqul khairat (Sudarsono, 2007: 47).

Perilaku Rasulullah SAW., sebagai seorang pedagang yang sangat terkenal kejujurannya, sehingga beliau mendapatkan gelar Al-Amin. Sebagaimana dikatakan Muhammad Ridha, bahwa Rasulullah, Saw., ketika berusia dua puluh lima tahun, karena kemuliaan akhlaknya, penduduk Arab memberi gelar "al-Amin" (Ridho, t.t.: 42).

Rasulullah Saw., sebagai seorang Rasul memiliki empat sifat wajib (sidik, fatonah, amanah, tabligh) yang perlu dicontohkan oleh seluruh umat manusia dalam menjalankan semua aspek kehidupan dalam mencapai kebahagiaan du dunia maupun di akhirat, termasuk dalam bermuamalah antar sesama manusia, tidak terkecuali tenaga penjualan bank syariah.

Dengan demikian perilaku etika penjualan yang baik menurut ajaran syariat Islam, akan mengacu pada empat sifat Rasul, yakni memiliki sikap sidik, fatanah, amanah, dan tabligh.

\section{a. Sidik (jujur)}

Kata sidik, berdasarkan kamus besar bahasa Indonesia berarti: benar, jujur. Sedangkan menurut Syekh Muhammad Nawawi, sidik adalah kesesuaian antara berita yang disampaikan dengan fakta (Ibnu Umar AlJawi, t.t.: 41). Menurut Imam Ghazali, kata sidik mengandung enam maknya, yaitu benar dalam ucapan, niat dan keinginan, angan-angan, menepati janji, beramal, dan menegakkan agama (Al-Ghazali, vol. 4: 375).

Allah Swt., berfirman:

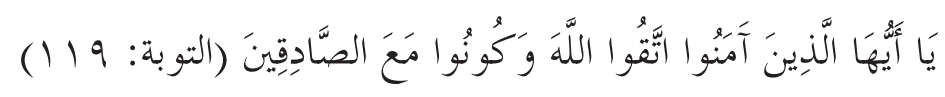

"Hai orang-orang yang beriman, bertakwalah kepada Allah dan hendaklah kamu bersama orang-orang yang benar". (QS. Al-Taubah (9): 119). 
Kata Ash-Shadiqin dalam ayat tersebut di atas, menurut Burusyawi dalam tafsir Ruh Al Bayan diartikan benar (jujur) dalam keadaan apapun atau mengatakan sesuatu dengan sebenar-benarnya (Al-Burusyawi, 2006: 635-636). Kata Ash-Shadiqin secara lebih luas dijelaskan dalam hadis Bukhari (no.6094) (Ibnu Alan al-Shiddiqi, 2005: 203-204):

Dalam sebuah Hadis diriwiyatkan Bukhari Muslim dari Ibnu Mas'ud: dari Rasulullah, Saw., mengatakan:

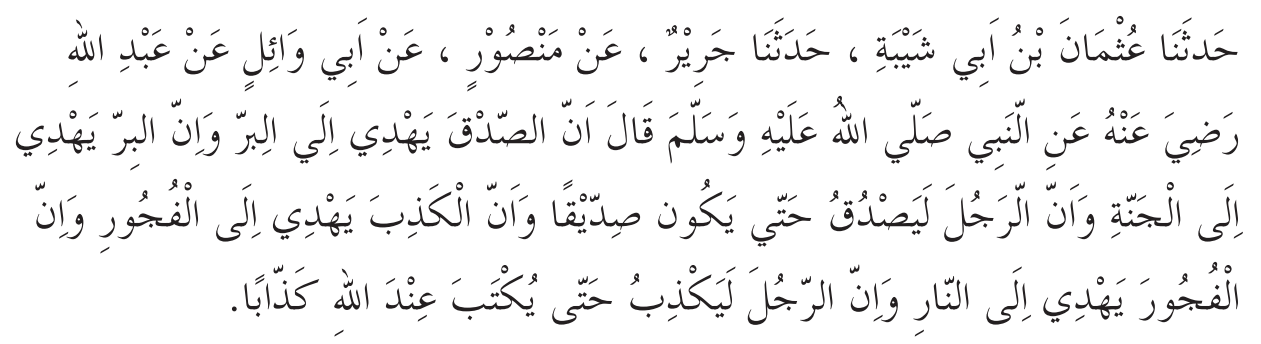

Artinya:

Diriwayatkan dari 'Usman Ibnu Abi Syaibah, dari Jarīr, dari Mansur, dari Abi Wa'il, dari Abdullah R.a. dari Rasulullah Saw., bersabda: "Sesungguhnya jujur (benar) itu mengantarkan kepada kebenaran. Dan kebenaran mengantarkan ke dalam surga. Seseorang yang berusaha untuk jujur akan dicatat oleh Allah sebagai orang jujur. Dan sesungguhnya dusta (kidzib) mengantarkan kepada kemaksiyatan. Dan kemaksiyatan mengantarkan kepada neraka. Dan orang yang selalu berdusta akan dicatat oleh Allah sebagai pendusta."

Selanjutnya kata sidik dijelaskan dalam sebuah Hadis :

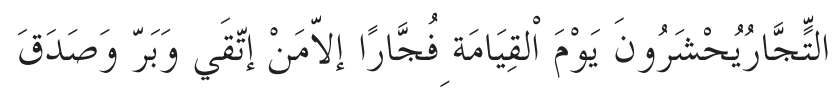

Artinya:

"Para pedagang akan dikumpulkan di hari kiyamat sebagi pendusta kecuali hanya orang-orang yang bertakwa, benar, dan jujur."

Yang dimaksud kata bir (benar) dalam hadis diatas adalah berbuat baik dengan tidak menyakiti hati orang lain dan juga tidak menyebabkan kemadlaratan orang lain, sedangkan kata sidiq (jujur) artinya menghihindari sumpah palsu. 
Lebih jauh dikatakan bahwa dengan kejujuran dan kemampuannya ternyata Muhammad mampu benar memperdagangkan barang-barang Khadijah, dengan cara yang lebih banyak menguntungkan daripada yang dilakukan orang lain sebelumnya. Demikian juga dengan perangainya yang manis dan perasaannya yang luhur ia dapat menarik kecintaan dan penghormatan Maisaroh kepadanya (Kamaluddin, 2009: 66).

Kamaluddin (2008) menyatakan salah satu diantara tip-tip praktis Rasulullah dalam berjualan adalah mencintai konsumen. Rasulullah Saw., pernah bersabda tentang cara mencintai pelanggan: a) "Allah itu mengasihi orang yang bermurah hati, ketika menjual, ketika membeli dan ketika menagih." (HR. Bukhari dari Jabbir bin Abdullah); b) "Tidak dibenarkan seorang Muslim menjual satu jualannya yang mempunyai aib sebelum dia menjelaskan." (HR. Al-Quzuwaini), c). "Saudagar yang jujur dan dapat dipercaya masuk dalam golongan para nabi, orang-orang jujur, dan para syuhada." (HR. Tirmidzi) (Kamaluddin, 2009: 67).

Sikap sidik dapat ditampilkan melalui kejujuran dalam hal menepati janji, terbuka dan jujur bila terdapat kelemahan dan kekurangan tentang produk bank syariah yang ditawarkan, menyampaikan informasi tentang ketersediaan produk bank syariah, dan persaingan penjualan produk bank syariah.

1). Menepati janji. Kata ash-Shadiqin, dalam tafsir Al qurtubi para mufasirin berbeda pendapat, salah satunya ash-Shadiqin mempunyai arti menepati janji (Al-Qurtubi, [1420 H] 2000: 183), sebagaimana disebutkan dalam Surah Al Ahzab ayat 23:

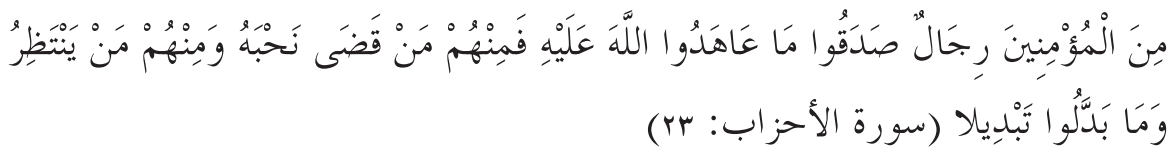

Artinya:

"Di antara orang-orang mukmin itu ada orang-orang yang menepati apa yang telah mereka janjikan kepada Allah; maka di antara mereka ada yang gugur. Dan di antara mereka ada (pula) yang menunggununggu dan mereka sedikit pun tidak merubah (janjinya)." (QS. Al Ahzab [33]: 23). 
Dalam dunia bisnis, kejujuran bisa juga ditampilkan dalam bentuk kesungguhan dan ketepatan (mujāhadah dan itqān), baik ketepatan waktu, janji, pelayanan, pelaporan, mengakui kelemahan dan kekurangan (tidak ditutup-tutupi) yang kemudian diperbaiki terus menerus, serta menjauhkan diri dari berbohong dan menipu (baik kepada diri sendiri, teman sejawat, perusahaan, maupun mitra kerja). Termasuk memberikan infomasi yang penuh kebohongan. Bisnis yang dipenuhi kebohongan dan manipluasi seperti ini insya Allah tidak akan mendapat rahmat dan barokah dari Allah s.w.t. (Hafidhudin dan Tanjung, 2003: 73). IbnuMiskawaih (1968) menyatakan sebaliknya, praktik - praktik yang menghasilkan keuntungan yang tidak jujur, tidak terhormat dan memalukan melalui penipunan, pengelabuhan, pengkhianatan, pencurian atau ketidakadilan (Miskawayh, 1968).

Dengan demikian sudah selayaknya seorang tenaga penjualan yang memegang prinsip etika bedasarkan syariat Islam akan selalu menepati janji yang diberikan kepada siapapun khususnya kepada pelanggan, demikian halnya tenaga penjualan bank syariah akan selalu tepat waktu dalam menjalankan tugas sesuai jam kerja yang ditentukan.

2). Terbuka dan jujur dalam hal bila terdapat kekurangan dan kelemahan produk, ketersediaan produk, dan persaingan penjualan. Sidik diartikan orang yang memiliki kesamaan antara lahir dan batinnya. Sebagaimana dikatakan Ibnu Al Arabi (Al-Qurtubi, [1420 H], 2000: 183) bahwa yang demikian itu merupakan hakekat tujuan yang ingin dicapai, untuk menghilangkan kemunafikan di dalam akidahnya dan sifat yang tidak sesuai dengan perbuatannya.

Senada dengan Ibn al-Ukhuwwah (1983) mengemukakan, menurut prinsip-prinsip Islam, penjual dituntut untuk "mengungkapkan semua kekurangan yang ada pada barang-barang mereka, baik yang kelihatan atau yang tersembunyi; sebaliknya, kalau tidak begitu berarti merupakan perilaku curang (Ibn Al-Ukhuwwah, 1983). Niazi (1996) juga menegaskan, wajib bagi penjual untuk mengungkapkan semua yang cacat baik yang diketahui maupun yang tidak dapat dilihat (Niazi, 1996: 196). Selain itu, Tyser et al., (1967) menyatakan bahwa sebuah penjualan yang tanpa syarat apapun maka barang yang dijual harus bebas dari cacat. Nabi 
Muhammad (s.a.w.) secara tegas mengutuk semua perilaku manipulatif, dengan menyatakan bahwa, "Orang yang menipu kita bukanlah salah satu dari kami”" (Al-Nawawi, t.t.: 770).

Seorang tenaga penjualan yang berpegang pada syariat Ialam akan mengungkapkan dengan terbuka dan jujur bila terdapat kelemahan dan kekurangan produk bank syariah yang ditawarkan. Demikian hal akan bersikap terbuka dan jujur dalam menyampaikan informasi tentang ketersediaan produk bank syariah. Artinya tenaga penjualan tidak akan menawarkan produk yang pada kenyataannya tidak dimiliki bank syariah tersebut. Disamping itu pula tenaga penjualan bank syariah bersikap terbuka dan jujur dalam hal persaingan penjualan produk, baik secara individu maupun kelembagaan. Tenaga penjualan menghindari perbuatan yang mendhalimi terhadap sesama tenaga penjual dengan memanfaatkan kelemahan dan kekurangan sesama tenaga penjualan untuk mendapatkan reputasi dan prestasi. Demikian halnya terhadap sesama lembaga keuangan lainnya. Dengan demikian yang dimaksud sidik disini adalah sikap kejujuran tenaga penjualan yang ditampilkan melalui tepat janji, keterbukaan dan jujur bila terdapat kelemahan dan kekurangan produk, ketersediaan produk, dan persaingan penjualan.

\section{b. Fatanah}

Kata fatanah, dalam kamus besar bahasa Indonesia artinya pintar, cerdik, cerdas. Menurut Syekh Muhammad Nawawi (Ibnu Umar Al Jawi, t.t.: 44), fatanah adalah kemampuan kecerdasan dalam menyampaikan argumentasi. Fatanah dapat diartikan sebagai intelektual, "kecerdasan atau kebijaksanaan". Potensi yang paling berharga dan termahal yang hanya diberikan pada manusia adalah akal (intelektualitas).

Allah berfirman:

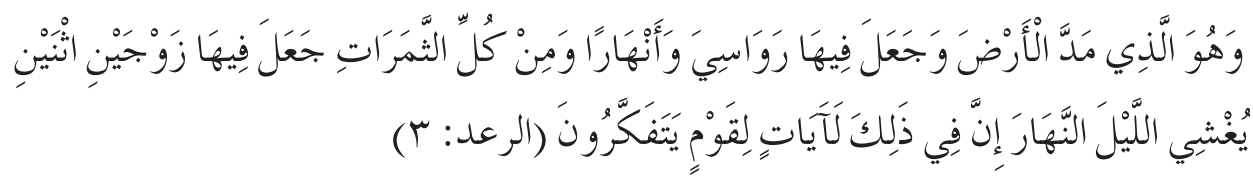

Artinya:

"Dan Dialah Tuhan yang membentangkan bumi dan menjadikan gunung-gunung dan sungai-sungai padanya. Dan menjadikan padanya 
semua buah-buahan berpasang-pasangan. Allah menutupkan malam kepada siang. Sesungguhnya pada yang demikian itu terdapat tandatanda (kebesaran Allah) bagi kaum yang memikirkannya" (QS alRa'd (13): 3).

Sifat fatanah (kecerdasan) Nabi Muhammad Saw., ditulis oleh Muhammad Husain Haekal (1965) dalam kitabnya Hayāt Muhammad, bahwa Abu Talib mencintainya kemenakannya itu sama seperti Abdul Muttalib. Karena kecintaanya itu pula, ia mendahulukan kemenakannya dari pada anak-anaknya sendiri. Budi pekerti Muhammad yang luhur, cerdas, suka berbakti dan baik hati, itulah yang menarik hati pamannya (Haikal, 2006: $58)$.

Demikian halnya tenaga penjualan hendaknya memiliki sikap fatanah (kecerdasan) dalam menyampaikan informasi maupun pertanyaan nasabahnya dengan benar. Seorang tenaga penjualan akan memberi jawaban bila benar-benar mengetahui dan memahami pokok permasalahan yang ditanyakan oleh pelanggannya, dan sebaliknya tenaga penjualan tidak akan pernah memberi jawaban terhadap pertanyaan pelangan, bila benar-benar belum mengetahui dan memahaminya, karena disadari bahwa hal demikian itu pada akhirnya akan membuat penyesalan dan kekecewaan pelanggan.

Dalam dunia bisnis, tidak menutup kemungkinan bila terjadi seorang tenaga penjualan secara sengaja memberikan jawaban yang menyesatkan terhadap pelanggan dengan maksud dan tujuan untuk mendapatkan sesuatu yang pada akhirnya merugikan orang lain. Perilaku yang demikian itu merupakan perilaku yang tidak etis karena melanggar syariat Islam, padahal semua perbuatan yang dilakukan di dunia akan dipertanggungjawabkan di hadapan Allah kelak di akhirat. Disinilah pentingnya kecerdasan spiritual bagi setiap tenaga penjualan dalam semua bidang usaha. Sebagaimana dikemukakan Agustian bahwa kecerdasan yang dimaksud disini adalah kecerdasan spiritual, yaitu kemampuan untuk memberi makna ibadah terhadap setiap perilaku kegiatan, melalui langkah-langkah dan pemikiran yang bersifat fitrah, menuju manusia seutuhnya (hānif), dan memiliki pola pemikiran tauhid (integralistik), serta berprinsip hanya karena Allah (Agustian, 2001).

Berdasarkan uraian di atas, maka yang dimaksud fatanah dalam hal ini adalah kemampuan kecerdasan spiritual tenaga penjualan dalam memberi- 
kan informasi yang dibutuhkan pelanggan, berdasarkan apa yang benarbenar telah diketahui olehnya.

\section{c. Amanah}

Kata amanah, dalam kamus besar bahasa Indonesia artinya dapat dipercaya. Kata $A l$ amānāt, jamak dari kata Amānah, yang berarti segala sesuatu yang hendak dijaga oleh seseorang baik berupa kewajiban-kewajiban agama, hak-hak maliyah, amal-amal sariyah, kekuasaan pemerintahan, menjaga titipan sesuai kemampuan (Ali fauzan, 2006: 220).

Sementara menurut Syek Muhammad Nawawi (t.t.: 42-43), amanah adalah terjaga dari segala sesuatu yang dilarang oleh Allah. Sesuatu yang dilarang oleh Allah baik lahir maupun batin. Aspek lahir misalnya berbuat zina, minum khamr, berdusta dari segala kemaksiyatan, sedangkan aspek batin misalnya sifat khasud, sombong, riya', cinta dunia. Seorang pebisnis haruslah memiliki sifat amānah, karena Allah menyebutkan sifat orang-orang mukmin yang beruntung adalah yang dapat memelihara amanat yang diberikan kepadanya.

Allah Swt., berfirman:

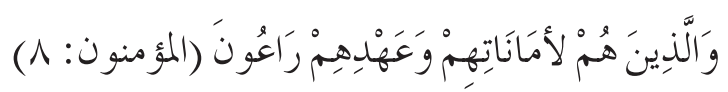

Artinya:

"Dan orang-orang yang memelihara amanat-amanat dan janjijanjinya" (QS al-Mu'minūn [23]: 8).

Dalam suatu riwayat dikemukakan bahwa setelah Fathu Makkah (Pembebasan Mekah), Rasulullah Saw., memanggil Utsman bin Thalhah untuk meminta kunci Ka'bah. Ketika Utsman menghadap Nabi untuk menyerahkan kunci itu, berdirilah al-'Abbas seraya berkata: "Ya Rasulullah, demi Allah, serahkan kunci itu kepadaku. Saya akan rangkap jabatan tersebut dengan jabatan siqāyah (urusan pengairan)." Utsman menarik kembali tangannya. Maka bersabdalah Rasulullah: "Berikanlah kunci itu kepadaku, wahai 'Utsman!" 'Utsman berkata: "Inilah dia, Amanah dari Allah." Maka berdirilah Raulullah membuka Ka'bah dan kemudian keluar untuk tawaf di Baitullah. Lalu turunlah Jibril membawa perintah supaya kunci itu diserahkan 
kembali ke 'Utsman. Rasulullah melaksanakan perintah itu sambil membaca ayat tersebut di atas (QS. An Nisā' [4]: 58) (Az-Zuhaili, jilid 3, 2003: 127). Sementara dalam Al-Ibriz, dijelaskan, 'Utsman sangat kagum karena kunci yang semula diminta dengan paksa, tetapi bahwa setelah kunci selesai digunakan setelah itu dikembalikan lagi kepada 'Utsman. Dikarenakan pada saat turun ayat (QS. An Nisā' [4]: 58) dan ketika dibacakan oleh Syayidina Ali, akhirnya seketika itu pula 'Utsman masuk Islam (Bisri, t.t.: 219).

Dari kisah turunnya ayat tersebut di atas dapat diambil pelajaran, betapa mulianya akhlak Rasulullah Saw., dalam mengemban amanat, dan ketika amanat tersebut sudah waktunya harus disampaikan kepada yang berhak, seketika itu pula diserahkan kepada yang memiliki haknya.

Rasulullah Saw., bersabda, "Bahwa amanah akan menarik rezeki, dan sebaliknya khianat akan mengakibatkan kefakiran". (HR al-Dailami).

Amanah dalam konteks pembahasan disini adalah seorang tenaga penjualan mampu menjaga sikap amanah, artinya benar-benar dapat dipercaya memelihara segala sesuatu yang menjadi hak pelanggannya baik berupa materiil maupun immateriil.

Hak pelanggan yang berupa materiil misalnya berupa bagi hasil, hadiah, bonus, dan penghasilan lain dari perusahaan. Seorang tenaga penjualan yang benar-benar amanah tidak akan mengambil ataupun mengurangi sedikitpun hak pelanggan tanpa persetujuannya. Sebagaimana Yusuf AlQardhawi menyatakan bahwa konsekuensi amanah adalah mengembalikan setiap hak kepada pemiliknya, baik sedikit ataupun banyak, tidak mengambil lebih banyak dari pada yang ia miliki, dan tidak mengurangi hak orang lain, baik itu berupa hasil penjualan, fee, jasa atau upah buruh (Al-Qardhawi, 2001: 298).

Segaimana Firman Allah:

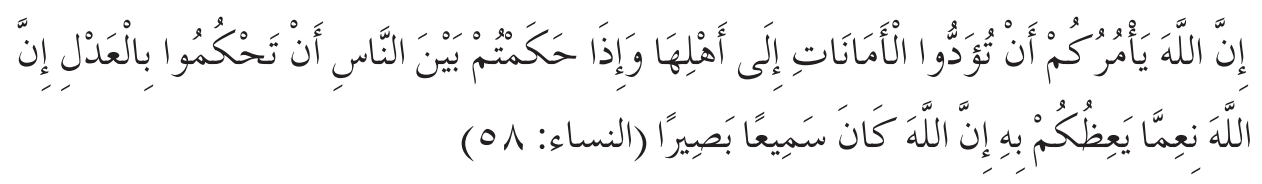

"Sesungguhnya Allah menyuruh kamu menyampaikan amanat kepada yang berhak menerimanya, dan (menyuruh kamu) apabila menetapkan 
dengan adil. Sesungguhnya Allah memberi pengajaran yang sebaikbaiknya kepadamu. Sesungguhnya Allah Maha Mendengar lagi Maha Melihat" (QS al-Nisā (4): 58).

Sedangkan hak pelaanggan yang berupa immateriil, misalnya tenaga penjualan yang amanah, saat memberikan layanan selalu memerhatikan hakhak pelanggan. Seorang tenaga penjualan yang amanah ketika memberikan layanan kepada setiap pelanggan akan memerhatikan hak-hak konsumen. Sehingga produk yang ditawarkan kepada pelanggan sesuai dengan yang diinginkan nasabah, dan tidak sekali-kali melakukan penekanan kepada pelanggan, karena tahu bahwa produk yang ditawarkan tidak sesuai dengan yang diinginkan pelanggan.

\section{d. Tabligh}

Kata tabligh, dalam kamus besar bahasa Indonesia artinya penyampaian. Sedangkan menurut Syek Muhammad Nawawi (t.t.: 43), tabligh adalah menyampaikan perintah Allah. Sifat-sifat Nabi Muhammad Saw., disebutkan oleh Muhammad Husain Haekal (1965) sebagai berikut: sifatnya yang sangat rendah hati, bila ada yang mengajakanya bicara ia mendengarkan hati-hati sekali tanpa menoleh kepada orang lain. Tidak saja mendengarkan kepada yang mengajaknya bicara, bahkan ia memutarkan seluruh badannya. Bicara sedikit sekali, lebih banyak ia mendengarkan. Bila bicara selalu sungguh-sungguh, tetapi sungguhpun demikian ia tak melupakan ikut membuat humor dan bersendau gurau, namun apa yang dikatakannya selalu yang sebenarnya. Bila ia marah tidak pernah sampai tampak kemarahannya. Semua itu terbawa oleh kodratnya yang selalu lapang dada, berkemauan baik dan menghargai orang lain. Bijaksana, murah hati dan murah bergaul. Mempunyai tujuan pasti, berkemauan keras, tegas dan tak pernah ragu dalam tujuannya (Haikal, 2006: 69).

Sebagaimana Allah berfirman,

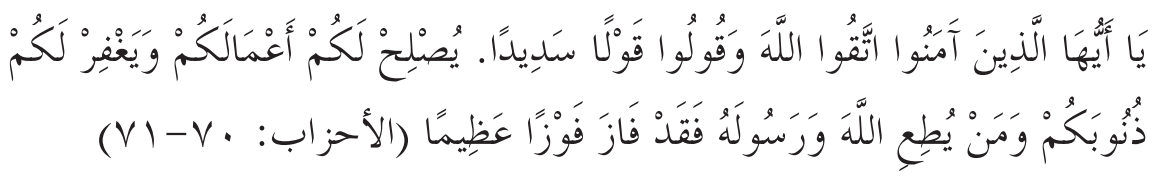


Artinya:

"Hai orang-orang yang beriman, bertakwalah kamu kepada Allah dan katakanlah perkataan yang benar (qaulan sadidan), niscaya Allah memperbaiki bagimu amal-amalmu dan mengampuni bagimu dosadosamu. Dan barang siapa menaati Allah dan Rasul-Nya, maka sesungguhnya ia telah mendapatkan kemenangan yang besar". (QS al-Ahzāb [33]:70-71).

Ali r.a., pernah mengatakan, "Ajaklah manusia berbicara dengan sesuatu yang mereka pahami, dan tinggalkan apa yang (tidak mereka mengerti). Apakah kamu ingin Allah dan Rasul-Nya didustakan"(HR: Bukhari).

Syariat Islam tidak ada ruang untuk membenarkan perilaku yang menipu. Al-Qur'an mengutuk segala bentuk pernyataan palsu, tuduhan tidak berdasar, dan kesaksian palsu.

Sebagaimana disebutkan dalam Alqur'an:

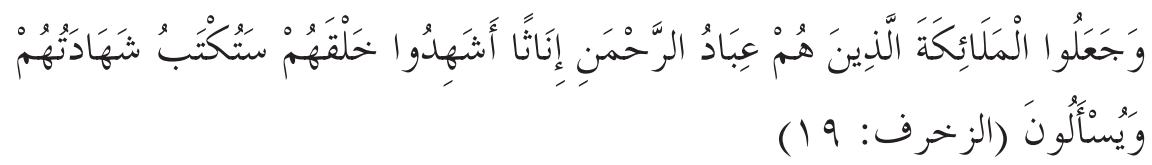

Artinya:

"Dan mereka menjadikan malaikat-malaikat yang mereka itu adalah hamba-hamba Allah Yang Maha Pemurah sebagai orang-orang perempuan. Apakah mereka menyaksikan penciptaan malaikatmalaikat itu? Kelak akan dituliskan persaksian mereka dan mereka akan dimintai pertanggungjawaban”. (QS. Al-Zukhruf [43]:19).

Dalam hal etika penjualan Islam, Ibn al-Ukhuwwah (1983), menyatakan bahwa adalah tidak etis bagi penjual atau petugas pemasaran memuji kualitas produk beserta atributnya secara berlebihan, namun dalam realita mereka tidak memilikinya. Saeed (2001) menyatakan bahwa, menurut prinsip-prinsip Islam, teknik promosi penjualan seharusnya tidak menggunakan daya tarik seksual, emosional, penakutan, iklan palsu, dan hasil penelitian palsu, semua mempunyai unsur-unsur dari paksaan, yang digolongkan sebagai perilaku tidak etis. Lebih jauh lagi, etika Islam melarang keras stereotip perempuan dalam iklan, dan menggunakan fantasi berlebihan. Penggunaan bahasa dan prilaku sugestif, serta penggunaan perempuan sebagai obyek 
untuk memikat dan menarik pelanggan juga tidak diperbolehkan (Saeed, 2001, vol. 32: 127-142).

Tabligh dalam konteks penelitian ini diimplementasikan melalui kemampuan tenaga penjualan dalam hal penyampaian kualitas produk beserta atributnya secara bijak sesuai realita, untuk menghindari kesan pemberian harapan yang berlebihan tentang kualitas produk yang ditawarkan kepada pelanggan.

\section{Kesimpulan}

Etika perilaku dalam utilitarian menekankan pada pendekatan positivistik (pengalaman) namun mengabaikan semua aspek transendental (aktualisasi tujuan hidup rohani yang lebih tinggi). Teori-teori sekuler ditafsirkan menurut keinginan dan perilaku dari masing-masing pelaku bisnis, yang berdampak pada kegagalan etika dalam memberikan layanan yang penuh arti.

Pandangan Islam memiliki pondasi yang kuat yang mendasarkan pada prinsip-prinsip kejujuran dan keadilan, dan memberikan arah dan tujuan dalam menciptakan nilai dan meningkatkan standar kehidupan masyarakat melalui usaha komersial selama mengikuti prinsip-prinsip ini. Pandangan Islam memberikan catatan yang sangat berharga dan sungguh unik mengenai aspek khusus tentang aktivitas manusia melalui tiga alasan: Pertama, Islam tidak mengakui adanya pemisahan antara urusan duniawi dan ukhrawi selama individu mencari keridhaan Allah dan mengikuti perintah-Nya dalam melakukan seluruh aspek aktivitas sehari-hari. Kedua, semua jenis usaha seseorang, termasuk usaha yang bertujuan komersial merupakan bagian dari kepercayaan agama. Dengan kata lain, segala sesuatu yang dilakukan seseorang adalah bagian dari ibadah kepada Allah. Ketiga, dalam Islam, semua usaha komersil (termasuk transaksi dalam penjualan) merupakan bentuk kegiatan dari ibadah.

Kesimpulannya adalah seluruh rangkaian aktivitas dalam kehidupan seseorang akan dipertanggungjawabkan di hadapan Allah. Melakukan transaksi-transaksi bisnis merupakan bagian dari kehidupan yang hakiki sehari-hari, dalam Islam setiap transaksi harus dilaksanakan menurut ajaran hukum Islam, yakni dengan sikap sidik, fatanah, amanah, dan tabligh. 


\section{Daftar Pustaka}

Al Burusyawi, Isma'il Haqqi, Ruh Al Bayan, Beirut: Dar Al Fikri, 1426$1427 \mathrm{H} / 2006 \mathrm{M}$

Ad-Dimasyqi, Muhammad Jamaludin Alqasimi, Mauizhatul Mukminin Min Ihya' Ulum Al-din, Terj. Moh Abdai Rathomy, Al-Maktabah AtTijjariyyah Al-Kubro, t.t.

Agustian, Ary Ginanjar, ESQ: Emotional Spiritual Quotient, Jakarta: Agra, 2001.

Fauzan, Shaleh ibnu Fauzan ibnu Abdullah Ali, Al Khuthab Al Manbariyah Fi Al Manasibat Al 'Ashriyah, Jilid 1, Ash Shomal: An Nur, 1426$27 \mathrm{H} / 2006 \mathrm{M}$.

Al Ghazali, Imam Abu Hamid Muhammad Ibnu Muhammad, Ihyā' Ulum Al Din, Jilid 4 Dar Ihyā' Al Kutub Al Arabiyah, tt.

Hafidhudin, Didin dan Henri Tanjung, Manajemen Syariah dalam Praktek, Jakarta: Gema Insani, 2003.

Haikal, Muhammad, Husain, Hayât Muhammad, Cetakan ke-9, Cairo, Egypt: Dar al-Maaref, Terj. Ali Audah, Sejarah Hidup Muhammad, Cetakan ketigapuluh tiga Jakarta: Dunia Pustaka Jaya, 2006.

Hunt, S.D., \& Vitell, S.J., "A general theory of marketing ethics", Journal of Macromarketing, 1986, Vol. 6, No. 1, p. 5-16.

Ibn al-Ukhuwwah, Diya' al-Din Muhammad, Ma'alim al-Qurbah fi Ahkam al-Hisbah, Translated by Reuben Levy, Luzak, London, 1983.

Isma'il, Al-Bukhari, Abi Abdillah Ibnu Muhammad Ibnu, Al Bukhari, Jilid 4, Beirut: Dar Al Fikr, 1426-1427 H/ 2006 M.

Al Jawi, Syekh Muhammad Nawawi Ibnu Umar, Fath al-Majid, Surabaya: Al Hidayah, t.t.

Kamaluddin, Laode dan Aboza M. Richmuslim, Cerdas Bisnis Cara Rasulullah, Bagaimana Rasulullah Saw. Bisa Cepat Kaya di Usia Muda Hanya Bermodal Cinta, Jakarta: Richmuslim Adikarya Bangsa, 2009.

Al Makkiyyi, Muhammad Ibnu 'Alan Al Shiddiqi Asy Syafi'i Al 'Asy'ari, Dalil Al Fālihīn, (Beirut: Dar Al Fikr, 1425-1426 H/ 2005 M.

Miskawayh Ibn, Ahmad Ibn Muhammad: 1968, The Refinement of Character, trans. by Constantine K. Zurayk, Beirut: The American University of Beirut, 1968.

Muslich, Etika Bisnis Islam, Landasan Folosofis, Normatif, dan Substansi Implementatif, Yogyakarta: Ekonisia, 2004. 
Musthofa, Bisri, Al-Ibrīz, Li Ma'rifah Tafsir Alquran Al Azīz, Juz 1-10 Kudus: Menara Kudus, t.t.

Nadwi, Abul Hassan Ali, "The Most Suitable Religion for Mankind", in Altaf Gauhar (ed.), The Challenge of Islam, Islamic Council of Europe, London, 1978.

Al-Nawawi, Imam (nd) "Riyadhus-Saleheen," trans., S. M. M. Abasi, IIPH, Riyadh. 2, p. 770.

Netty Hartati, dkk, Islam \& Psikologi, Jakarta: RajaGrafindo, 2004.

Niazi, L.A.K., Islamic Law of Contract, Lahore: Research Cell, Dayal Sing Trust Library, 1996), p. 196.

Alqurtubi, Abi Abdillah Muhammad Ibnu Ahmad Al Anshori, Tafsir Alqurtubi, Beirut: Dar Al Kutub Al Alamiyah, 1420 H/2000 M.

Raji. Al-Faruqi, Ismail:, AL TAWHID: Its Implications for Thought and Life, Kuala Lumpur: IIIT, 1992.

Ridho, Muhammad, Muhammad Rasulullah Saw., Dar Ihyā al-Kitāb al'Arabiyyah.t.t.

Saeed, Mohammad, Zafar U. Ahmed, Seda Masoda Mukhtar, "International Marketing Ethics an Islamic Perspective: A Value-Maximization Aprroach", Journal of Bisnis Ethics, 2001, Vol. 32, No.2, hlm. 127142.

Safi, L., The Foundation of Knowledge A Comparative Study in Islamic and Western Methods of Inquiry, Kuala Lumpur: IIIT, 1996.

Shaleh dan Dahlan, Asbābun Nuzūl, Latar Belakang Historis Turunnya Ayatayat al-Quran, Edisi Kedua, Bandung: Penerbit Diponegoro, 2007

Sihombing, Sabrina, Oktoria, Hubungan Sikap Dan Perilaku Memilih Satu Merek: Komparasi Antara Theory Of Planned Behavior Dan Theory Of Trying, Disertasi Universtas Gajah Mada Yogyakarta, 2004.

Sudarsono, Heri, Bank dan Lembaga Keuangan Syariah, Deskripsi dan Ilustrasi, Yogyakarta: Ekonisia, 2007

Al-Utsmaimin, Syaikh Muhammad bin Shalih, Syarah Riyadus Shalihin, Jilid 3, Terj. Ali Nur (Jakarta Timur: Darus Sunnah Press, 2007

Wiranata, I Gede A.B., Etika Bisnis \& Hukum Bisnis (Sebuah Pemikiran Awal), Bandar Lampung: Penerbit Universitas Lampung, 2010.

Yosephus, L. Sinour, Etika Bisnis, Pendekatan Filsafat Moral Terhadap Perilaku Pebisnis Kontem Forsyth, S. J., "A Taxonomy of Ethical Ideologies", Journal of Personality and Social Psychology, 1980, 
Vo. 39, No.1, p. 175-184. porer, Jakarta: Yayasan Pustaka Obor Indonesia, 2010.

Az-Zuhaili, Wahbah, At-Tafsir Al-Munir, Fi Al Aqidah wa Asy-Syar'iyah wa Al-Manhaj, Jilid 3, Damaskus: Dar Al-Fikr, 1424 H/ 2003 M. 